\title{
Transcription Factor HES-4
}

National Cancer Institute

\section{Source}

National Cancer Institute. Transcription Factor HES-4. NCI Thesaurus. Code C104259.

Transcription factor HES-4 (221 aa, $24 \mathrm{kDa}$ ) is encoded by the human HES4 gene. This protein plays a role in transcriptional repression. 